\title{
Methodology for assessment of total stability of regional high-yield budgets of Russia
}

\author{
Magomed Tashtamirov*, Arsan Hasbulatov, and Jamalai Gesuev \\ Chechen State University, A. Sheripova Str., 32, 364060 Grozny, Russia
}

\begin{abstract}
The stability of the budget system allows the national economy to ensure overall stability not only in the fiscal aspect, but also in many other areas of public activity. Risks of instability in one segment of the budget structure can cause a cascade of problematic aspects and negatively affect the overall balance of the country's budget system. Fiscal policy in Russia is still unable to solve the problem of increasing the financial autonomy of a certain category of regional budgets that have a high degree of subsidy dependence. Stable maintenance of the number of high-yield budgets of the country's constituent entities causes additional risks of the fiscal policy instability. In this regard, the research of the formation and state of regional budgets with a high subsidy dependence is quite relevant, especially in the context of increased external challenges. This article is aimed at multi-dimensional identification of problematic aspects of the stability level of the regional high-yield budgets of Russia in terms of their balance, stability and debt burden, which will determine their current state in current conditions. Analysis of the dynamics of revenues and expenditures of a regional high-yield budgets group with the determination of the level of their balance over the past three years is carried out. Methodology for a comprehensive assessment of the overall level of regional budgets' stability has been developed, including 5 main groups that reflect the quantitative and qualitative characteristics of regional finance. Analysis of the budget stability of high-yield regions of Russia is carried out. The main positive and negative aspects that characterize the state of the regional high-yield budgets of the country are identified.
\end{abstract}

\section{Introduction}

Ensuring the long-term balance and sustainability of the budget system budgets of the Russian Federation is one of the key areas of the public finance management system reform, implemented since 2010. At present, analysis of the balance and stability of regional budgets, which is characterized by a rather high level of uncertainty and significant budget risks due to the economic effects of the coronavirus pandemic, is of particular relevance. Monitoring the situation in this area is very important for improving the effectiveness of regional budget policy measures, solving the tasks of achieving sustainable inclusive economic growth and creating favorable living conditions for the population of the country and its regions. The problem of balancing regional budgets is quite actively

\footnotetext{
* Corresponding author: basxo@yandex.ru
} 
discussed in scientific publications on public finance. It is researched in the general context of fiscal sustainability and the quality of public finance management, in connection with the development of mechanisms to ensure long-term fiscal sustainability in the process of strategic budget planning, analysis of the debt burden and financial and budgetary security of the subjects of the Russian Federation, the state and execution of budgets, assessment of the degree of territorial public legal entities' financial independence and the development of inter-budgetary relations [1-4]. However, despite a wide range of case researches, the economic literature has not developed a unified approach to determining the essence of budget balance and its quantitative assessment.

Budget and tax (fiscal) regulation of regional and federal finances plays a huge role in issues of effective economic management, especially during periods of changing economic cycles. Thus, in the EU countries, changes in fiscal rules during periods of increasing economic turbulence lead to a change in the cyclical nature of economic development [5]. Over the past couple of decades, many countries have adopted fiscal rules to ensure financial sustainability. Fiscal rules impose long-term constraints on fiscal policy through numerical constraints on fiscal aggregates [6]. Maintaining fiscal stability is very important, both for macroeconomic stability and for the country's financial capabilities [7].

The research area concerning high-yield budgets of the country's constituent entities, which financial and economic component causes many problems in the process of increasing budget security, is particularly relevant to the issues of ensuring the stability of the territorial entities' budgets. Regional budgets, which share of subsidies exceeds the $40 \%$ threshold in their own revenue, have a higher risk of losing the level of balance, since they do not have formed financial instruments and levers of influence on negative environmental factors. In the event of deterioration in the regional economic environment or macroeconomic stability, the group of high-yield budgets will be in state of imbalance. The fall in regional budget revenues and the decline in the annual volume of inter-budgetary assistance have extremely negative consequences. At the heart of the budget revenue opportunities of any level are primarily economic prerequisites that allow one to form the necessary amount of the tax base. The way out of the situation with a low level of budget balance can be two main directions, as noted in scientific works: stimulating subsidization and stimulating regional economic potential [8]. Considering the first direction, it should be noted that the increase in the subsidization of regional budgets in Russia has been occurring in recent years, which has led to the "dependency syndrome" in the category of high-yield budgets [9]. Such trends only increase the degree of risk in the implementation of unfavorable factors (financial, fiscal, and economic), which can reduce the level of regional budgets' stability, especially in the group of high-yield ones [10-11].

The Russian Federation is characterized by an extremely high degree of economic spatial unevenness of its territorial entities. In this regard, the strengthening of global and macroeconomic threats that can realize the risks of financial system instability requires the search for effective tools for analyzing the state of stability level and stability of the country's constituent entities' budgets, which are the main ones for ensuring the effective dynamics of the regional finance development. Given the lack of a generally accepted methodology for assessing the level of the country's regional budgets' stability in terms of their balance and stability, it is advisable to identify the most vulnerable budget system's segments. According to the author, such segments are the category of high-yield regional budgets of Russia, which financial and budgetary viability is at a critical level. Accordingly, taking into account the above mentioned, it is necessary to determine the degree of stability and balance of the country's high-yield budgets as the most vulnerable category of regional finance in order to activate the mechanism for preventing systemic risks of the budget structure's instability. 
The main goal of this research is aimed at multi-dimensional identification of problematic aspects of the stability level of the regional high-yield budgets of Russia in terms of their balance, stability and debt burden, which will determine their current state in current conditions.

The subject of the research is a set of budget and financial processes that affect the level of budget stability of regional high-yield budgets. Achievement of this goal is seen through the solution of the following tasks:

1. To form a comprehensive methodology for assessing the budget sustainability of the regional budget, which allows identifying internal problems in achieving balance.

2. To assess the dynamics of the revenue and expenditure parts of the regional highyield budgets of Russia;

3. To conduct a comprehensive analysis of the sustainability level of Russia's regional high-yield budgets through an aggregated indicator;

4. To identify the place of regional high-yield budgets of Russia in the system budget stability of the country.

\section{Type of high-yield budgets and methods for determining balance}

To assess the level of sustainability of regional high-yield budgets in Russia, it is necessary to consider the dynamics of the balance of this group of budgets. Taking into account the author's previous research, it should be noted that in Russia in the last 15 years, a relatively stable group of high-yield regional budgets has been formed in the number of 6 subjects (the Republics of Dagestan, Ingushetia, Chechnya, Tyva, Altai and Kamchatka Territory).

The share of subsidies from the federal budget in the revenues of these regions is consistently maintained at over $40 \%$, which indicates their budgetary and financial independence.

The revenue side of regional high-yield budgets has grown steadily over the past three years (see Figure 1). The highest growth is observed in the Altai Republic - about $20 \%$ on average for the period, while the lowest value is in the Republic of Ingushetia $-7.8 \%$.

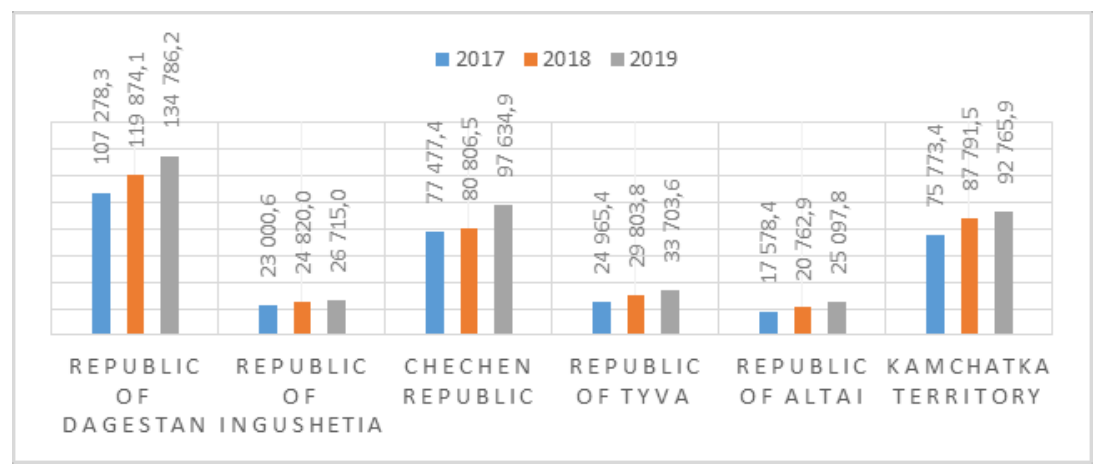

Fig. 1. Dynamics of regional high-yield budgets' revenues of Russia for the period 2017-2019, million rubles

The costs of this group of regional budgets also increased in the same way as the revenue growth, which is clearly shown in Figure 2. The growth rate of the expenditure part corresponds to the dynamics of revenue for the subjects of the country. 


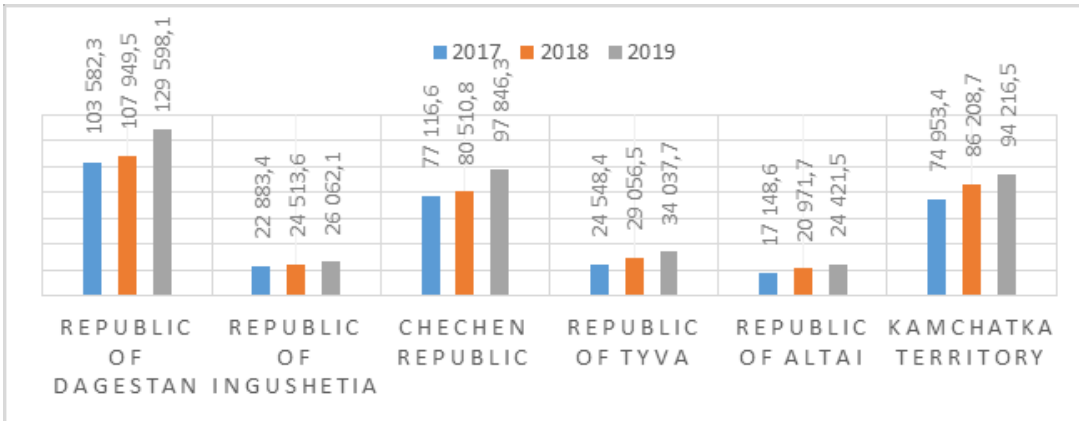

Fig. 2. Dynamics of regional high-yield budgets costs of Russia for the period 2017-2019, million rubles

However, it is important to note that the growth of the revenue part was largely ensured not by a similar increase in tax and non-tax revenues, but by increasing the volume of interbudget transfers to this group of regions, which were allocated by the federal budget. Thus, for each of the 6 regions, the growth rate of gratuitous aid averaged from $10 \%$ to $20 \%$ per year, which is comparable to the dynamics of revenue and costs growth.

In matters of assessing the level of regional budgets' balance, the balance coefficient, which is the coefficient of the revenue and costs parts, is important. The results of calculating the balance coefficient are shown in Figure 3.

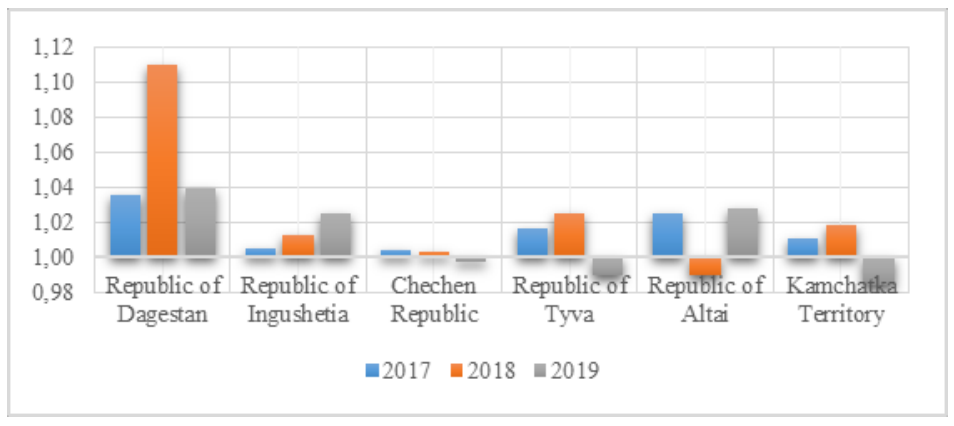

Fig. 3. Results of regional high-yield budgets' balance coefficient of Russia for the period 2017-2019

Based on the calculations obtained, it follows that the balance level of regional highyield budgets is more positive. 4 regions were unbalanced over the past three years: in 2019 - the Chechen Republic, the Republic of Tyva and the Kamchatka Territory; in 2018 - the Republic of Altai. The results obtained reflect a fairly high balance of the studied group of regional budgets in terms of the ratio of revenue and costs. Low level of deficit allows these regions not to resort to borrowing on the domestic market and to maintain insignificant amounts of state regional debt.

\section{Analysis of the aggregate level of budgetary sustainability of regional high-yield budgets}

The satisfactory balance of regional high-yield budgets is not sufficient reason to believe that this group of regions has a similar sufficient fiscal stability. For a comprehensive analysis of the regional high-yield budgets stability, it is necessary to use the method of aggregated assessment, which is proposed by the author in the form of the following groups 
of indicators that reflect the overall level of fixity and stability of the regional budget, presented in Table 1.

Table 1. Groups and indicators of a comprehensive assessment of the fiscal and financialeconomic state of the subsidized region.

\begin{tabular}{|c|c|c|c|}
\hline $\begin{array}{l}\mathbf{N} \\
\mathbf{o}\end{array}$ & Indicator & Calculation formula & Standard values \\
\hline \multicolumn{4}{|c|}{ Group 1-level of subsidization } \\
\hline 1 & $\begin{array}{l}\text { Subsidy } \\
\text { coefficient }\end{array}$ & $\begin{array}{l}\qquad \mathrm{K}_{\mathrm{d}}=\mathrm{AS}_{\mathrm{i}} / \mathrm{OR}_{\mathrm{i}} \\
\mathrm{AS}_{\mathrm{i}}-\text { amount of subsidies provided in the i-th } \\
\text { region; } \\
\mathrm{OR}_{\mathrm{i}}-\text { own revenue of the } \mathrm{i} \text {-th region }\end{array}$ & $\begin{array}{c}\text { Moderate }-0.1-0.25 \\
\text { Unsatisfactory }-0.25-0.4 \\
\text { Crisis }->0.4\end{array}$ \\
\hline 2 & Per Capita subsidy & $\begin{array}{c}\mathrm{R}_{\mathrm{d}}=\mathrm{AS}_{\mathrm{i}} / \mathrm{P}_{\mathrm{i}} \\
\mathrm{P}_{\mathrm{i}}-\text { population of the } \mathrm{i} \text {-th region }\end{array}$ & $\begin{array}{l}\text { The higher the value, the } \\
\text { higher the dependence of } \\
\text { the budget services cost to } \\
\text { the population of the region } \\
\text { on subsidies }\end{array}$ \\
\hline \multicolumn{4}{|c|}{ Group 2- Budget sustainability } \\
\hline 3 & $\begin{array}{l}\text { Balance degree } \\
\text { coefficient }\end{array}$ & $\begin{array}{l}\mathrm{K}_{\mathrm{s}}=\mathrm{C}_{\mathrm{i}} / \mathrm{R}_{\mathrm{i}} \\
\mathrm{C}_{\mathrm{i}} \text { - costs of the i-th region; } \\
\mathrm{R}_{\mathrm{i}} \text {-revenue of the i-th region }\end{array}$ & $<1$ \\
\hline 4 & $\begin{array}{l}\text { Share of the } \\
\text { regional budget } \\
\text { deficit in tax and } \\
\text { non-tax revenues }\end{array}$ & $\begin{array}{l}\mathrm{DB}=\mathrm{C}_{\mathrm{i}}-\mathrm{R}_{\mathrm{i}} / \mathrm{C}_{\mathrm{i}}-\mathrm{GA}_{\mathrm{i}} \\
\mathrm{GA}_{\mathrm{i}} \text { - gratuitous aid of the } \mathrm{i} \text {-th region }\end{array}$ & $0.1-0.15$ \\
\hline 5 & $\begin{array}{l}\text { Financial } \\
\text { dependency } \\
\text { coefficient }\end{array}$ & $\mathrm{K}_{\mathrm{fa}}=\mathrm{GA}_{\mathrm{i}} / \mathrm{R}_{\mathrm{i}}$ & $\begin{array}{l}\text { The higher the value, the } \\
\text { higher the financial } \\
\text { dependence }\end{array}$ \\
\hline \multicolumn{4}{|c|}{ Group 3-debt burden } \\
\hline 6 & $\begin{array}{l}\text { Coefficient of the } \\
\text { region's state debt } \\
\text { to tax and non-tax } \\
\text { revenue }\end{array}$ & $\begin{array}{c}\mathrm{K}_{\mathrm{gd} / \mathrm{d}}=\mathrm{PD}_{\mathrm{i}}-\mathrm{BL}_{\mathrm{i}} / \mathrm{R}_{\mathrm{i}}-\mathrm{GA}_{\mathrm{i}} \\
\mathrm{PD}_{\mathrm{i}}-\text { amount of public debt of the } \mathrm{i} \text {-th region; } \\
\mathrm{BL}_{\mathrm{i}}-\text { amount of budget loans of the } \mathrm{i} \text {-th region }\end{array}$ & $\begin{array}{l}<0.5 \text { - moderate } \\
0.5-1 \text { - crisis }\end{array}$ \\
\hline 7 & Debt burden level & $\mathrm{DN}=\mathrm{PD}_{\mathrm{i}} / \mathrm{R}_{\mathrm{i}}-\mathrm{GA}_{\mathrm{i}}$ & $\begin{array}{c}\text { Moderate }-0.3-0.5 \\
\text { Unsatisfactory }-0.5-0.8 \\
\text { Crisis }->0.8\end{array}$ \\
\hline \multicolumn{4}{|c|}{ Group 4- budget focus } \\
\hline 8 & $\begin{array}{l}\text { Share of social } \\
\text { costs in the } \\
\text { regional budget }\end{array}$ & $\begin{array}{l}\qquad \mathrm{AV}=\mathrm{HE}_{\mathrm{i}}+\mathrm{CSP}_{\mathrm{i}}+\mathrm{CE}_{\mathrm{i}} / \mathrm{C}_{\mathrm{i}} \\
\mathrm{HE}_{\mathrm{i}} \text { - healthcare costs of the i-th region; } \\
\mathrm{CSP}_{\mathrm{i}} \text { - costs for social policy of the } \mathrm{i} \text {-th region; } \\
\mathrm{CE}_{\mathrm{i}} \text { - costs for the education of the } \mathrm{i} \text {-th region }\end{array}$ & $\begin{array}{l}\text { The greater the value, the } \\
\text { greater the role of subsidies } \\
\text { in the social security of the } \\
\text { region }\end{array}$ \\
\hline \multicolumn{4}{|c|}{ Group 5-impact of the budget on the regional economy } \\
\hline 9 & $\begin{array}{l}\text { Share of regional } \\
\text { (tax and non-tax) } \\
\text { revenues in GRP }\end{array}$ & 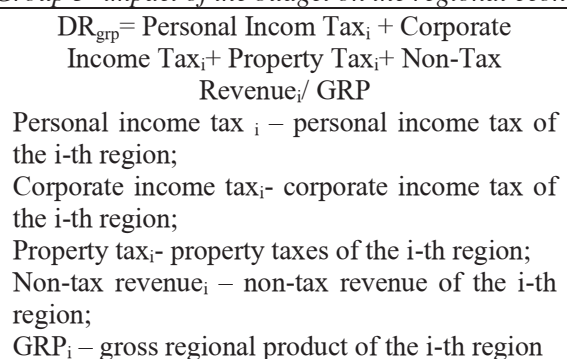 & $\begin{array}{l}\text { The higher the value, the } \\
\text { lower the financial stability } \\
\text { in the region }\end{array}$ \\
\hline 10 & $\begin{array}{l}\text { Coefficient of per } \\
\text { capita budget } \\
\text { financing }\end{array}$ & $\mathrm{Kbf}=\mathrm{Ci} / \mathrm{Pi}$ & $\begin{array}{l}\text { The higher the value, the } \\
\text { higher the provision of the } \\
\text { regional population with } \\
\text { budget funds }\end{array}$ \\
\hline 11 & $\begin{array}{l}\text { Total accumulated } \\
\text { indicator }\end{array}$ & $\overline{T A I}=\sqrt[m]{\prod_{i=1}^{n} \mathrm{X}_{i}}$ & $\begin{array}{c}\text { Moderate }-0.2-0.3 \\
\text { Unsatisfactory }-0.3-0.4 \\
\text { Crisis }->0.4\end{array}$ \\
\hline
\end{tabular}


The presented indicators and the final aggregated cumulative index, which includes the calculation of the geometric average of 2, 5, 7 and 8 coefficients, will determine the level of total budget stability of the country's regional high-yield budgets. The data for calculating the coefficients are taken from the resource of the Federal Treasury of the Russian Federation for 2019.

Calculation results of the budgetary stability of the regional high-yield budgets of Russia are presented in Table 2. At the same time, to identify the extent of the gap between the studied group of budgets and the country's indicators, a comparative assessment was carried out with the average values of each coefficient of all 85 subjects of Russia.

Table 2. Calculation results of the total budget fixity and stability of the regional high-yield budgets of Russia for 2019.

\begin{tabular}{|c|c|c|c|c|c|c|c|}
\hline Indicator & $\begin{array}{l}\text { The } \\
\text { Republic of } \\
\text { Ingushetia }\end{array}$ & $\begin{array}{c}\text { The } \\
\text { Republic } \\
\text { of Tyva }\end{array}$ & $\begin{array}{l}\text { The } \\
\text { Chechen } \\
\text { Republic }\end{array}$ & $\begin{array}{c}\text { The } \\
\text { Republic } \\
\text { of } \\
\text { Dagestan }\end{array}$ & $\begin{array}{l}\text { The Altai } \\
\text { Republic }\end{array}$ & $\begin{array}{c}\text { Kamchatka } \\
\text { Territory }\end{array}$ & $\begin{array}{c}\text { Average } \\
\text { in the } \\
\text { country }\end{array}$ \\
\hline \multicolumn{8}{|c|}{ Group 1-level of subsidization } \\
\hline $\begin{array}{c}\text { Subsidy } \\
\text { coefficient }\end{array}$ & 0.58 & 0.576 & 0.568 & 0.553 & 0.473 & 0.419 & 0.14 \\
\hline $\begin{array}{l}\text { Per Capita } \\
\text { subsidy }\end{array}$ & $26,573.7$ & $56,058.0$ & $33,524.4$ & $22,555.6$ & $51,396.5$ & $12,1823.3$ & $14,301.4$ \\
\hline \multicolumn{8}{|c|}{ Group 2- Budget sustainability } \\
\hline $\begin{array}{c}\text { Balance degree } \\
\text { coefficient }\end{array}$ & 0.98 & 1.01 & 1.00 & 0.96 & 0.97 & 1.02 & 0.99 \\
\hline $\begin{array}{c}\text { Share of the } \\
\text { regional budget } \\
\text { deficit in tax and } \\
\text { non-tax revenues }\end{array}$ & -0.147 & 0.041 & 0.011 & -0.119 & -0.09 & 0.04 & -0.014 \\
\hline $\begin{array}{l}\text { Financial } \\
\text { dependency } \\
\text { coefficient }\end{array}$ & 0.83 & 0.76 & 0.81 & 0.68 & 0.71 & 0.58 & 0.31 \\
\hline \multicolumn{8}{|c|}{ Group 3- debt burden } \\
\hline $\begin{array}{l}\text { Coefficient of } \\
\text { the region's state } \\
\text { debt to tax and } \\
\text { non-tax revenue }\end{array}$ & 0 & 0.126 & 0.051 & 0.016 & 0.045 & 0.039 & 0.22 \\
\hline $\begin{array}{c}\text { Debt burden } \\
\text { level }\end{array}$ & 0.624 & 0.336 & 0.328 & 0.292 & 0.338 & 0.153 & 0.449 \\
\hline \multicolumn{8}{|c|}{ Group 4- budget focus } \\
\hline $\begin{array}{l}\text { Share of social } \\
\text { costs in the } \\
\text { regional budget }\end{array}$ & 0.68 & 0.64 & 0.72 & 0.66 & 0.58 & 0.42 & 0.56 \\
\hline \multicolumn{8}{|c|}{ Group 5- impact of the budget on the regional economy } \\
\hline $\begin{array}{l}\text { Share of regional } \\
\text { (tax and non-tax) } \\
\text { revenues in GRP }\end{array}$ & 0.080 & 0.139 & 0.105 & 0.070 & 0.161 & 0.191 & 0.16 \\
\hline $\begin{array}{l}\text { Coefficient of } \\
\text { per capita budget } \\
\text { financing }\end{array}$ & $52,333.5$ & $105,054.7$ & 67.156 & $41,995.5$ & $111,513.6$ & $299,100.1$ & $120,461.5$ \\
\hline $\begin{array}{c}\text { Total } \\
\text { accumulated } \\
\text { indicator }\end{array}$ & 0.68 & 0.58 & 0.61 & 0.55 & 0.53 & 0.39 & 0.36 \\
\hline
\end{tabular}

Consider the results of the analysis for each group of indicators:

1. Level of subsidization. The average value of the subsidy coefficient for the country is 0.14 , that is, $14 \%$ - is the share of subsidies from the revenue part on average for all regions of the country. At the same time, all the regions under consideration have results significantly higher than the Russian indicator. Per capita subsidy reflects the amount of subsidies allocated for each resident of the region. The highest values are traced in the Republics of Tyva and Altai, while the Kamchatka Territory is characterized by an indicator below the average for all regions of the country. Such high expenditures of subsidies per resident of high-yield regions show a high unevenness and a gap not only 
between the subjects of the country, but also between the subsidized regions themselves, and also reflect a significant social orientation of the studied group of budgets.

2. Budget sustainability. According to the coefficients reflecting the balance of budgets, the results are relatively positive or moderate, with the exception of the Republics of Tyva, Chechnya and Kamchatka Territory, where there is a budget deficit, but all values are below the established norm, which indicates that there are no problems with financing costs at the expense of the revenue part. However, the third indicator of the group - the coefficient of financial dependence is significantly higher in all the regions under consideration compared to the regional average indices $(0.31)$. The highest results are observed in the Republics of Ingushetia (0.83) and Chechnya (0.81), respectively, the lowest- the Kamchatka Territory (0.58). Vast majority of the costs of the high-yield regions group are financed by the gratuitous aid provided.

3. Debt burden. This group of indicators reflects the stable position of the considered group of budgets, since the low volume of the deficit does not force the authorities to resort to significant borrowing and increase public debt.

4. Social burden of the budget. The high-yield budgets of the Russian regions are characterized by a significant amount of spending on social needs (social policy, education and health care), which is characteristic of this group of regions. The Kamchatka Territory differs in this sense $(0.42)$, which value is lower than the average for the regions of the country (0.56). At the same time, the high share of social spending in the regions does not correspond to the similarly high indicator of per capita subsidization, which indicates that there is no connection between these indicators.

5. Budget impact on the regional economy. This group of indicators does not include the entire possible list of indicators that allow one to assess the impact of the budget on the regional economy, but it reflects trends. Regional tax component of high-yield regions does not occupy a significant place in the gross regional product of the subjects. A more interesting result is the budget per capita financing, which, with the exception of the Kamchatka Territory, is significantly lower than the average values for the regions of the country. If the indicator of the Chechen Republic is 2 times lower than the regional average, then the Republic of Dagestan is 3 times lower. A significant amount of per capita subsidization, which is higher than the average values for the regions of Russia, does not lead to a similarly high total budget financing of the population of high-yield regions.

\section{Conclusions}

In such a way, the comprehensive analysis of the total budget stability of regional highyield budgets revealed their low level in comparison with the regions of Russia on average (0.36). As the total final indicator shows, all 6 regions have a value higher than the optimal value for the country. The lowest aggregate fiscal stability is observed in the Republics of Ingushetia (0.68) and Chechnya (0.61), while higher in the Kamchatka Territory (0.39), but also lower than the average for the regions of Russia. Positive aspects of the stability of regional high-yield budgets are the presence of balance, which is a consequence of the high financial dependence on federal inter-budget transfers, which eliminates the need to find sources of financing for the regional budget deficit and the increase in public debt. But the main problem according to the results of the analysis is the high vulnerability of this group of regional budgets to negative factors and challenges that can significantly reduce the degree of financial stability and lead to budget imbalance. This circumstance should be taken into account when developing fiscal methods for regulating the budget system, especially during periods of changing economic cycles and economic instability. 


\section{Acknowledgements}

The research was carried out with the financial support of the RFBR in the framework of scientific project No. 20-010-00460.

\section{References}

1. E. Goryunov, L. Kotlikoff, S. Sinelnikov-Murylev, Economic issues, 7, 5 (2015)

2. O.V. Buklemishev, D.L. Mikhaylov, V.V. Soloviev, Financial Journal, 3, 34 (2018)

3. M.V. Milchakov, Financial journal, 66 (2016)

4. M.A. Pechenskaya, A.I. Povarova, Under scientific, Vologda: ISERTRAN, 110 (2016)

5. B. Gootjes, J. De Haan, Journal of International Money and Finance, 102276 (2020)

6. A. Schaechter, T. Kinda, N. Budina, A. Weber, A New Dataset, IMF Working Paper, 187 (2012)

7. A. Dornean, D.-C. Oanea, Procedia Economics and Finance, 20, 163 (2015)

8. N.A. Volobuev, D.A. Sizova, T.V. Sizova, Financial management, 100 (2020)

9. M.R. Tashtamirov, Finance and Credit, 1099 (2020)

10. N. Chalenko, K. Solodovnikova, Society and Economy, 11, 31 (2020)

11. Z.K. Tavbulatova, M.R. Tashtamirov, N. Kulakova, M.I. Nazaeva, EpSBS, Conference: SCTCGM 2018 - Social and Cultural Transformations in the Context of Modern Globalism, 1655 (2019) 